Boston University School of Law Scholarly Commons at Boston University School of Law

Faculty Scholarship

Winter 1-26-2015

\title{
Punishment and Blame for Culpable Indifference
}

Kenneth Simons

Boston University School of Law

Follow this and additional works at: https://scholarship.law.bu.edu/faculty_scholarship

Part of the Criminal Law Commons

\section{Recommended Citation}

Kenneth Simons, Punishment and Blame for Culpable Indifference, 58 Inquiry: An Interdisciplinary Journal of Philosophy 143 (2015). Available at: https://scholarship.law.bu.edu/faculty_scholarship/102

This Article is brought to you for free and open access by Scholarly Commons at Boston University School of Law. It has been accepted for inclusion in Faculty Scholarship by an authorized administrator of Scholarly Commons at Boston University School of Law. For more information, please contact lawlessa@bu.edu. 


\section{BU School of Law}

\section{PunishmeNT AND BLAME FOR CULPABLE INDIFFERENCE}

Forthcoming in Inquiry: An Interdisciplinary Journal of Philosophy (2014)

Boston University School of Law Public Law \& Legal Theory Research Paper No. 14(July 2, 2014)

Kenneth W. Simons

Boston University School of Law

This paper can be downloaded without charge at:

http://www.bu.edu/law/faculty/scholarship/workingpapers/2014.html 


\section{Punishment and Blame for Culpable Indifference}

by

Kenneth W. Simons*

Draft: February 20, 2014

\section{Introduction}

In criminal law, the "mental state" ${ }^{1}$ of the defendant is a crucial determinant of the grade of crime that the defendant has committed. Sometimes it also determines whether the defendant's conduct is criminal.

A common hierarchy of mental states, in order of decreasing culpability, is the following:

1. Purpose to cause a harm;

2. Knowledge (or belief ${ }^{2}$ ) that one will, or that one is very likely to, cause a harm;

3. Recklessness, i.e. belief that there is a substantial risk that one will cause a harm;

4. Negligence, i.e., where the actor should be aware of a substantial risk that she will cause a harm. ${ }^{3}$

This hierarchy describes mental states as applied to result elements, such as causing a death in the crime of homicide. Purposely or knowingly causing a death is typically categorized as murder, recklessly causing a death is often categorized as involuntary manslaughter, and negligently causing a death as negligent homicide. A similar hierarchy describes mental states as applied to circumstance elements, such as whether the defendant's sexual partner does not consent, or whether the defendant has violated a prohibition on engaging in conduct with an underage person (such as selling alcohol to a person under the age of 21), or whether the goods that defendant

\footnotetext{
* Professor of Law, The Honorable Frank R. Kenison Distinguished Scholar in Law, Boston University School of Law. (C) 2013. All rights reserved. I am grateful for comments from participants at the Conference on Moral and Legal Accountability, sponsored by Centre for the Study of Mind in Nature, University of Oslo, Norway, June 24-25, 2013.

${ }^{1}$ I use quotation marks because criminal law codes standardly classify negligence as a mental state for these purposes, yet negligence is often defined to include grossly deficient conduct or skill. Perhaps it is more accurate to speak, not of "mental state" requirements, but of "culpability requirements other than the voluntary act requirement and the lack of justification or excuse."

2 "Knowingly" is the term most often used in criminal statutes, but the relevant mental state is actually belief. "Knowingly" is simply a convenient shorthand for two requirements-the mental state of belief, and the truth of the matter believed. If a statute requires knowledge that a victim of sexual assault does not consent, then the state must prove both that defendant believed the victim did not consent and that the victim actually did not consent.

${ }^{3}$ This hierarchy is most carefully articulated in the Model Penal Code, which has been influential in American criminal law. See Model Penal Code §2.02(2). I have simplified its definitions in the text.
} 
possesses are in fact stolen. Thus, one can purposely possess stolen property, knowingly do so, recklessly do so, or negligently do so. Although grading punishment according to mental state is much less common with respect to circumstance elements of offenses than with respect to result elements, the hierarchy nevertheless is important, because it can affect the minimal culpability that a legislature or court selects for criminalization. Even if sexual offenses are not graded according to mental state, for example, it is an important question of policy and principle whether the prosecution must prove the actor's purpose, knowledge, recklessness, or instead negligence with respect to the victim's nonconsent.

One notable feature of this hierarchy is its emphasis on cognitive rather than conative mental states. With the exception of purpose, all of the relevant mental states make essential reference to the actor's beliefs (or, in the case of negligence, to what the actor should have believed). The point of imposing criminal liability on those who cause harm that they believed was very likely to occur (or that they believed had a substantial chance of occurring) is not, of course, simply to punish actors who have acquired such beliefs. Rather, it is to punish them (a) for not taking proper account of those beliefs in acting, and (b) in proportion to the fault that (a) reveals. On the standard view, proceeding to act despite awareness of a highly probable risk of harm is ordinarily highly culpable, and deserving of significant punishment. Proceeding to act despite awareness of a substantial but not highly probable risk of harm is also culpable, but, ceteris paribus, deserves lesser punishment. So if I ride my bicycle at very high speed on a path shared with pedestrians, I am more culpable for choosing to maintain my speed despite recognizing a very high risk of colliding with a pedestrian, than for choosing to maintain my speed despite recognizing a much smaller risk of collision.

This modern hierarchy of mental states has much to commend it. The distinction between purpose and knowledge is virtually identical to the distinction drawn by the Doctrine of Double Effect, between harms that one intends (either as a means or end) and harms that one merely foresees as a side effect. ${ }^{4}$ In some criminal law contexts, including attempt, accomplice liability, and treason, the distinction is often critical, because purpose rather than knowledge is often the mental state required for conviction. And the distinction between recklessness and negligence is often sensible: knowingly taking a substantial risk of killing or injuring someone is usually more culpable than inadvertently creating the same risk of causing someone's death or injury.

However, I want to focus on two problems that the hierarchy raises. First, is the value of the cognitive distinctions overstated, especially the distinction between

\footnotetext{
${ }^{4}$ It is not entirely clear whether DDE presupposes a contrast between (1) purposely causing a harm and (2a) what criminal law would cause knowing causation of the side-effect, or merely (2b) what criminal law would call the reckless causation of that side-effect (which the actor foresees as a possible but not high risk). It is also unclear whether DDE is meant to apply, not just to the distinction between purposely and knowingly causing harms as side-effects, but also to the distinction between engaging in conduct for the purpose of satisfying a relevant circumstance, and acting with the knowledge that one will thereby satisfy that circumstance. For example, does DDE make it more difficult to justify, or does it judge more harshly, (1) purchasing stolen goods when one's desire or purpose is that the goods be stolen, rather than merely (2) purchasing stolen goods which one knows or suspects are stolen?
} 
knowledge and recklessness? Second, is the cognitive focus incomplete? Should conative features play a larger role? An affirmative answer to this question brings us to the central focus of this paper: can the mental state of "culpable indifference" address the deficiencies of the standard hierarchy? How should that mental state be defined? How should its use be limited? In a final section of the paper, I will briefly address how this analysis of indifference might, and might not, apply in the nonlegal domain of moral blame.

This paper largely assumes a nonconsequentialist perspective. Mens rea distinctions are generally more important in deontological theories, where they have intrinsic significance, than in consequentialist theories, where their relevance is merely contingent. ${ }^{5}$ The paper focuses on conduct that is otherwise impermissible or unjustifiable, and then evaluates some of the considerations that determine the degree of the actor's culpability for that wrong. However, mental state criteria are sometimes also relevant in law and morality to justifiability, an issue I largely put aside for present purposes.

\section{Questioning the emphasis on cognitive mental states}

An actor's beliefs about the harm he will or might cause, or about the circumstantial features of his conduct that make his act wrongful or harmful, are certainly highly relevant to how blameworthy he is. But they cannot be the whole story.

First, beliefs, considered in isolation, say nothing about blameworthiness. They matter for criminal law only insofar as the actor could and should have acted differently in light of them. Perhaps I know that my neighbor plans to steal a smartphone tomorrow. Perhaps I know that I have a strong desire to steal a smartphone a week from now. Neither belief is, by itself, the proper foundation of criminal liability, if (as is quite plausible) we are not justified in imposing significant duties to prevent crimes by others and not justified in imposing attempt liability on those who have taken no steps towards the completed crime. Or, suppose I discover, after I have faultlessly pulled my car out of the driveway late at night, that a drunk neighbor was lying underneath my car, and my car crushed him to death. My ex post knowledge obviously has no bearing on my criminal liability.

Second, acting unjustifiably in the face of clear knowledge of the risks of my activity, while culpable, is not always more culpable than acting unjustifiably in the face of lesser (or no) knowledge of those risks. A product manufacturer that conducts a thorough cost-benefit analysis of the safety benefits and risks of a particular design, but makes an improper judgment that the benefits slightly outweigh the risks, is less culpable than a manufacturer that does not even bother researching the safety risks because it wishes to rush the product to market. ${ }^{6}$ Someone who actually recognizes a small risk that his sexual partner is not consenting but misreads the cues as signaling consent because of his sexual inexperience might be less culpable than a supremely selfish person who is

\footnotetext{
${ }^{5}$ See Finkelstein (2002); Simons (1992).

${ }^{6}$ See Simons (2012); Fletcher, p. 315.
} 
completely oblivious to the obvious signs that his sexual partner is frightened of his advances because he is concentrating entirely on his own sexual satisfaction.

Third, when a person's activities are widespread, either temporally or spatially, she will often be aware, as a statistical matter, of a virtual certainty that her conduct will cause harm. But that is hardly enough to judge her conduct as presumptively wrongful, much less as seriously wrongful. I should not be guilty of knowingly destroying the property of another simply because I choose, over my lifetime, to drive 700,000 miles by automobile and thus can predict at least one faultless accident causing such harm. Wal-Mart should not be guilty of knowingly hiring undocumented workers simply because, given its scale, and apart from how vigorously it screens its employees, it knows to a statistical certainty that thousands of its workers are undocumented. ${ }^{7}$

Fourth, although the distinction between knowingly and recklessly causing harm sometimes should make a legal and moral difference, often that distinction is swamped by other features relevant to culpability. In a fascinating recent article, Francis Shen and his coauthors report a careful empirical examination of whether ordinary people are able to understand and apply the Model Penal Code's hierarchical culpability structure (purpose, knowledge, recklessness, and negligence). ${ }^{8}$ They discover that when subjects were asked to sort concrete factual scenarios between these categories, and also to assign a level of punishment for each scenario, subjects were able to accurately and reliably distinguish between purposeful and knowing, between reckless and negligent, and between negligent and blameless. However, subjects were quite incapable of distinguishing reliably between knowing and reckless. Although the reasons for this failure are unclear, one explanation is as follows: ordinary citizens do not see why a mere increase in the level of risk that a defendant believes he is creating should be a decisive factor in judging the defendant's culpability (notwithstanding the views to the contrary of the Model Penal Code drafters and the many legislatures that have adopted the hierarchy). ${ }^{9}$

The discovery that ordinary citizens have enormous difficulty drawing the distinction between knowledge and recklessness is sobering. But in one respect the discovery is not so surprising. For, as we shall see in the next section, several legal doctrines explicitly recognize the inadequacy of the simple knowledge/recklessness distinction.

Fifth, a cognitive emphasis is easier to justify under a choice-based retributive account than under a character-based account. Although much ink has been spilled on the question of which account is preferable, and which particular version of the account is most satisfactory, ${ }^{10}$ here I will simply note some concerns about using either account to the exclusion of the other. Choice-based accounts tend

\footnotetext{
${ }^{7}$ For an extensive discussion of this problem, suggesting that statistical knowledge should not be judged as presumptively unjustifiable or wrongful except in limited circumstances (e.g. when the actor knowingly imposes a high, concentrated risk of serious harm on another), see Simons (2012). ${ }^{8}$ Shen.

${ }^{9}$ I am currently working with several of the authors of this study on follow-up studies to investigate more carefully the reasons why subjects did not distinguish knowledge and recklessness, and also to investigate subjects' reactions to some of the culpable indifference categories discussed in this paper.

${ }^{10}$ See, e.g., Duff (2002).
} 
to emphasize the cognitive dimensions of culpability, while character-based accounts emphasize other dimensions, especially the conative, volitional, and affective. Yet neither account is plausible, either as an interpretation or justification of legal doctrine, if it entirely ignores the other dimensions.

Thus, a choice-based account that purports to focus only on what the actor knew about the risks and other relevant characteristics of his conduct at the time of his criminal act cannot sensibly restrict itself to identifying the beliefs that the actor possessed at that time (in light of which he should have acted differently). Beyond this, it must make controversial normative judgments about what efforts the actor must make to acquire knowledge, to retain or bring to current awareness knowledge that she acquired earlier or to which she has latent access, or to infer danger from facts of which she is quite aware. Such an account also must, to be plausible, give some consideration to such subtle factors as the actor's opportunity for reflection, the firmness of his beliefs and intentions, and his capacity for resisting emotional pressures in the situation. ${ }^{11}$

At the same time, a character-based account focused entirely on whether the actor's conduct failed to conform to what a person of good character would do or feel is woefully deficient both in interpreting and justifying legal mental state categories. For example, how are we to make sense of degrees of culpability on such an account? To be sure, criteria of negligence are often articulated in this manner: ordinary negligence is failure to comply with the standard of care that a reasonable person would exercise; gross negligence requires a large deviation from that standard. But is intentional killing really best understood as an "extraordinarily gross deviation" from the standard of care that a virtuous or reasonable person would exercise? Moreover, a long-standing objection to character theories of criminal culpability is their dubious guidance for how we should treat "out-of-character" acts. ${ }^{12} \mathrm{X}$ might have been a paragon of virtue until the day of the killing, but if he loses his temper and unjustifiably kills $\mathrm{V}$, that spotless record has no obvious bearing on the punishment he justly deserves. Y might have been insufferably callous and mean-spirited until the day of the killing, but this has no obvious bearing on whether his conduct on that day was unjustifiable or on how unjustifiable or culpable it was. To be sure, the fact that conduct flows from a settled, "vicious" character trait might sometimes have significance. If the trait is one that the actor cannot be fully blamed for acquiring (suppose he is the 16-year old son of white supremacists), the fact that the trait is settled and difficult to change might have exculpatory significance. If it is one for which he is more responsible (suppose he has spent years carefully training to be a cold-hearted contract killer), it might inculpate. But the story to be told must be more nuanced than simply whether the act flows from a vice of character.

\footnotetext{
${ }^{11}$ Defensive doctrines of duress and provocation cannot be explained without reference to this last factor. See Duff (2015) (this volume).

${ }^{12}$ Similarly, within virtue theory, Tom Hurka has argued that the primary locus of virtue is occurrent desires, actions, and feelings, apart from their connection to more stable dispositions and traits: Imagine that, walking down the street, you see someone kick a dog from an evident desire to hurt the dog just for the pleasure of doing so. Do you say, 'That was a vicious act' or 'That was a vicious act on condition that it issued from a stable disposition to give similar kicks in similar circumstances'? Surely you say the former.

Hurka (2006), p. 71.
} 


\section{Supplementing cognitive mental states}

Notwithstanding the cognitive emphasis of modern mental state hierarchies, several legal doctrines broaden the focus. This section identifies three. The first two treat some instances of recklessness as legally equivalent to knowledge. The third treats some instances of negligence as legally equivalent to recklessness. These doctrines together underscore the inadequacy of the modern hierarchy. But the doctrines pose problems of their own, which will be discussed in the subsequent section.

\section{A. Depraved heart murder}

Consider this example:

Torturer: D1 subjects V to physical beating and torture, for his own malicious gratification. D1 realizes that he is endangering V's life, but his plan is to keep $\mathrm{V}$ alive in order to prolong his own pleasure. $\mathrm{V}$ dies from the abuse.

Notice that D1 does not count as a murderer under the simple hierarchy, because he lacks the purpose to kill his victim, and also lacks knowledge that his acts are practically certain to kill the victim. If we were to apply the hierarchy, he would be guilty only of reckless manslaughter, not murder. But he certainly seems highly culpable, and at least as culpable as many purposeful or knowing killers.

One widely-recognized category of murder in American jurisdictions is "depraved heart" or "extreme indifference" murder, ${ }^{13}$ which is meant to capture cases such as this, as well as cases in which an actor deliberately shoots a gun into an occupied car or into an occupied house, or in which an actor plays Russian Roulette with another. This category is essentially a subcategory of reckless killings in which the actor seems as culpable as a knowing or purposeful killer. ${ }^{14}$

\footnotetext{
${ }^{13}$ Here is an explanation of the concept from a leading American case:

When an individual commits an act of gross recklessness for which he must reasonably anticipate that death to another is likely to result, he exhibits that "wickedness of disposition, hardness of heart, cruelty, recklessness of consequences, and a mind regardless of social duty" which proved that there was at that time in him "the state or frame of mind termed malice."

Commonwealth v. Malone.

${ }^{14}$ Some European legal systems, especially Germany and the Netherlands, recognize a somewhat similar concept, dolus eventualis. This, too, is a subcategory of reckless actors, embracing those who "accept" the risk of the harmful side-effects of their conduct and thus should be punished at a level comparable to purposeful (dolus directus) or knowing (dolus indirectus) actors. "Acceptance" is a notoriously vague and controversial criterion. For a recent account of the controversy, see Blomsma, at pp. 99-133.
} 


\section{B. Willful blindness as constructive knowledge}

Suspicious smuggler: S hands D2 a locked box, together with the key, and asks D2 to transport the box to a friend of S's in another city, for $\$ 200$. S does not tell D2 what is in the box, but D2 knows that $S$ is a marijuana dealer. D2 transports the box without examining its contents. The box in fact contains marijuana.

In this case, the state might not be able to prove beyond a reasonable doubt that D2 "knows" that he is transporting marijuana, since knowledge often requires awareness of a very high probability that the legally relevant circumstance obtains. Drug offenses typically require knowledge, not merely recklessness (i.e., not merely awareness of a substantial risk that the circumstance obtains).

However, many courts interpret statutory knowledge requirements broadly, to encompass cases of "willful blindness," i.e., cases where the D2 is suspicious that the relevant circumstance obtains but deliberately avoids easy, further inquiry that would confirm his knowledge. This category is essentially a subcategory of recklessness as to a circumstance in which the actor's reason for not possessing the state of mind of knowledge is especially culpable.

\section{Intoxication as constructive recklessness}

Drunk driver: D3 has five beers at a party, knowing that he will be driving home. Because of his intoxication, he has trouble focusing on the road, and fails to see a pedestrian in the path of his car. He runs over and kills the pedestrian.

The state might not be able to prove beyond a reasonable doubt that D3 was consciously aware of a significant risk that he would kill the pedestrian, since he never perceived the pedestrian in his field of vision. ${ }^{15}$ Thus, absent a special rule, it might not be able to convict him of reckless manslaughter, and instead might be limited to a conviction of negligent homicide or a comparable crime, with a significantly lower penalty.

However, almost all courts expand the definition of recklessness, to encompass cases where the actor, due to voluntary intoxication, is unaware of a specific risk of harm that he is posing. ${ }^{16}$ This category is essentially a subcategory of negligence cases in which the actor has an especially culpable reason-voluntary

\footnotetext{
${ }^{15}$ One significant uncertainty is how to interpret the requirement of "conscious awareness of a substantial risk of death.” If it includes generalized awareness of diffuse future risks, then D3 might satisfy the requirement, because he probably recognizes that driving drunk creates a significantly increased risk of running over unseen pedestrians. But this broad interpretation is dubious, because it threatens to eviscerate the recklessness/ negligence distinction. Virtually all cases of negligent driving involve "awareness of risk" in this weak and diffuse sense. For example, most drivers know that if they get distracted by a cellphone call, by an angry comment from a passenger, or by the need to fiddle with the car's controls, they will create an increased risk of harm to others.

${ }^{16}$ See, e.g., Model Penal Code §2.08(2).
} 
intoxication—-for being unaware of the significant risk of harm that his conduct poses. ${ }^{17}$

IV. A closer look at culpable indifference as a legal category

A. The meaning of indifference

These supplementary categories have this in common: they expand criminal liability beyond the conventional modern (and mostly cognitive) hierarchy. But the first two categories also have in common some problematic features: their contours are vague, and they could result in dramatic increases in punishment and could apply in a very wide range of circumstances. These concerns about inconsistent application and lack of fair notice suggest the need for caution in the use of these categories. But, more fundamentally, the principle underlying the categories is not exactly pellucid. I will focus here on this fundamental question. ${ }^{18}$

Consider again depraved heart murder. The Model Penal Code, whose other definitions of mental state categories are relatively precise, and much more precise than traditional criminal law criteria, offers only this as a definition: homicide constitutes murder "when ... (a) it is committed purposely or knowingly; or (b) it is committed recklessly under circumstances manifesting extreme indifference to the value of human life."19

What in the world is "extreme indifference"? The presence of the modifier "extreme" provides a clue: "indifference" is not here meant in the sense of equipoise or lack of preference or desire. If I am indifferent whether we watch television or go for a walk, or whether Romney or Obama is elected, I am in a state of attitudinal equipoise. But equipoise exists or it does not; it cannot be "extreme" rather than, say, "mild."

Rather, in this context, "indifference" refers to an attitude towards causing a harm or wrong, an attitude that is to be contrasted with purpose. D might act with the purpose of causing $\mathrm{V}$ harm, but he also might act with indifference to that result, meaning, very roughly, that, although D did not desire the result, he cared very little about whether he caused that result, or he cared less than he should have. Acting with concern or care about the rights and welfare of others is something that can come in degrees. So an actor might be "extremely indifferent" if, say, she gives very little weight to a very serious wrong or harm in her practical reasoning; while another might be "mildly indifferent" if he gives substantial weight to the interests of others, but somewhat less than he should. The term "culpable indifference" might be preferable to "indifference" or even "mild" vs. "extreme indifference" because it better conveys what the relevant kind of culpability is - not a state of attitudinal equipoise, but a lack of proper concern for the rights and interests of others.

\footnotetext{
${ }^{17}$ Negligence itself might (at least in its aggravated forms) be analyzed as a species of culpable indifference. For discussion, see Baron; Simons (1994); Simons (Dimensions, 2002).

${ }^{18}$ For analysis of the vagueness and scope problems, see Simons (Culpable Indifference, 2002).

${ }^{19}$ Model Penal Code $\$ 210.2$ (1) (a), (b). The definition does add language presuming extreme indifference when the actor causes death in the course of committing certain serious felonies.
} 
To be sure, indifference has other senses. One ordinary language meaning is emotional insensitivity or callousness, a lack of feeling or affect. But this meaning is largely irrelevant in the criminal law, ${ }^{20}$ because the focus of legal mental state criteria is properly on whether the defendant acted unjustifiably, and on how blameworthy his conduct was, not on how he felt (or on what he did not feel) about what he was doing. Criminal law should punish for culpable acts and choices (and for omissions when one has a duty to act), not for objectionable or deficient desires, attitudes, beliefs, intentions, or feelings that are unconnected to acts.

\section{B. Disconnected attitudes: remorse, hope, and cruelty}

To underscore this point, consider three legal contexts in which the attitude of the actor towards the criminal wrong or harm might not be sufficiently connected to his commission of the wrong or causation of harm, and therefore might not justly bear on his criminal punishment: (1) an actor's remorse (or lack of remorse) for a past wrong; (2) his hope (rather than intention) that a wrong will occur; and (3) the actor's cruelty.

First, does it count against a finding of "extreme indifference" murder that the defendant, after killing the victim, felt enormous remorse? Does it count in favor that he felt no remorse, or was even delighted that he caused a death? The answer in both cases should be no. ${ }^{21}$ The question for criminal law should be whether the actor's attitude influenced the fact or the manner of the killing, not whether it demonstrates his good or bad character in responding to the killing. Perhaps the presence of remorse has a modest bearing on his proper sentence for other retributive or consequentialist reasons-e.g., because the defendant who shows remorse has accepted responsibility for his wrong and deserves some credit on his retributive "ledger."22 But an actor's post-act remorse is entirely consistent with the judgment that when he committed the criminal act itself, he was "indifferent" in the sense relevant to the criminal law. Similarly, the actor's ex post pleasure in the harm he has caused does not, by itself, demonstrate (or even enhance) his culpability for causing the harm.

\footnotetext{
${ }^{20}$ Largely but not entirely irrelevant: in evaluating whether a defendant is legally insane, it might be relevant whether the defendant has both affective and cognitive capacities to know that his conduct is wrong. But once the defendant satisfies these minimum capacities, it does not seem relevant to the degree of his deserved punishment whether he displayed enormous empathy, little empathy, or no empathy when he engaged in an action that harmed or endangered another. The (mostly) unfeeling Mr. Spock of Star Trek fame is not for that reason deserving of greater criminal punishment for otherwise unjustified conduct.

${ }^{21}$ See People v. Roe, in which the dissent argues that defendant's remorse after fatally wounding victim in Russian Roulette game undercut a finding of extreme indifference; the majority properly rejects the argument.

${ }^{22}$ The act of expressing remorse might also, to some extent, mitigate the emotional harm suffered by surviving members of the victim's family and other members of the community, and thus can properly be considered at sentencing. And a motive of remorse is also properly considered in determining whether an actor who has committed an attempt is entitled to a complete defense of abandonment of the attempt.
} 
Second, criminal law criteria occasionally make guilt depend on whether the actor "hopes" that a legally relevant circumstance exists. ${ }^{23}$ For example, under the Model Penal Code, if it is a crime to purposely receive stolen property, then one may commit the crime either by receiving property that one believes is stolen, or by receiving property that one "hopes" is stolen (even if, in the latter case, one believes that it is not stolen). ${ }^{24}$ Suppose acting with "hope" is understood in one of its ordinary language senses, as a desire for a state of affairs that the actor need not have any power to effectuate. By contrast, acting with the "intention" of satisfying a state of affairs does presuppose some power to effectuate that state. Thus understood, hope is a problematic basis for criminal liability. Consider an example. Jones buys property from Smith for a particular price, and she hopes it is stolen, because she will thereby impress her radical friends with her anarchist values. However, she believes the property is almost certainly not stolen, and its stolen quality plays no role in her decision to purchase or in the price she pays. Jones exhibits a reprehensible attitude, but why should that matter, if the attitude played no role whatsoever in her choices and actions? If "hope" is indeed a permissible basis for greater punishment, the implications are troubling. Should we punish a reckless driver more severely because he hoped that the victim would die, even if that desire played no role in how dangerously he drove? (Of course, if that desire did play such a role-for example, if the driver swerved as close as possible to the victim in order to harm the victim, or in order to increase the risk of an injury - then the driver's attitude is indeed sufficiently connected to his action that it may justly bear on the driver's sentence.) And conversely, the mere fact that an actor hopes that harm will not befall a victim is not relevant to his just punishment, if that benign hope was irrelevant to the actor's choices and conduct. ${ }^{25}$

Third, consider the relevance of "cruelty" to criminal liability. In states that impose the death penalty, a very common aggravating circumstance that helps support that penalty is that the murder was "especially heinous, atrocious, and cruel." Moreover, some states include cruelty as one factor supporting a finding of firstdegree murder. For example, Massachusetts defines first-degree murder as "Murder committed with deliberately premeditated malice aforethought, or with extreme atrocity or cruelty...,26

What is cruelty, for legal purposes? The authorized jury instruction for murder in Massachusetts states:

Extreme cruelty means that the defendant caused the person's death by a method that surpassed the cruelty inherent in any taking of a human life. ... You must determine whether the method or mode of a killing is so shocking as to amount to murder by extreme atrocity or cruelty. The inquiry focuses on

\footnotetext{
${ }^{23}$ For further discussion, see Simons, Culpable Indifference, at 237-239. Although "hope" is found in a number of criminal statutes, I have found no actual cases in which criminal liability turned on whether the actor hoped that $\mathrm{x}$ (even though the actor did not believe that $\mathrm{x}$ ).

${ }^{24}$ Model Penal Code \$2.02(2)(a)(ii): "A person acts purposely with respect to [the attendant circumstances of a crime if] he is aware of the existence of such circumstances or if he believes or hopes that they exist."

${ }^{25}$ See Ferzan, at p. 203.

${ }^{26}$ Ma. Gen. L. Ann. $265 \S 1$.
} 
the defendant's action in terms of the manner and means of inflicting death, and on the resulting effect on the victim.

The jury also is told to consider a range of specific factors, including, notably, "whether the defendant was indifferent to or took pleasure in the suffering of the deceased.", 27

But is it improper to consider this last factor in determining the defendant's criminal punishment? The practical stakes are great: classifying a case as firstdegree murder can mean the difference between mandatory life imprisonment and a much shorter prison term. In some cases, considering this factor seems entirely appropriate. Suppose C1 killed the victim in a particularly brutal manner for the very purpose of obtaining pleasure in the victim's suffering. That form of cruelty reflects an especially reprehensible motive. But imagine a different case. Suppose C2 kills his victim in a brutal manner, and discovers, to his surprise, that this brings him great pleasure. We might even suppose that C2 has killed before, and has never before derived any emotional satisfaction from the killing. Should C2's pleasure count in favor of imposing a much heavier punishment? Even if C2's violent actions are no different than what they would have been had C2 not obtained such pleasure ${ }^{28}$ (The jury instruction, read literally, suggests an affirmative answer.)

Whether the concept of "cruelty" does or should extend to cases such as C2 is uncertain. One source of the uncertainty is that cruelty might refer simply to engaging in particular types of acts, such as acts that cause gratuitous suffering, apart from the improper motives or inapt pleasures of the actor. A five year old who pulls the wings off a fly is cruel in this minimal sense simply because her act causes pointless suffering, even if she does not know that it does, and even if she does not act for that purpose. But if cruelty also has an attitudinal component, does it require a vicious or sadistic motive as in C1, or is it also satisfied by a vicious or sadistic attitude as in C2?

\footnotetext{
${ }^{27}$ The full list of factors that the jury is to consider is as follows:

In deciding whether the Commonwealth has proved beyond a reasonable doubt that the defendant caused the death of the deceased with extreme atrocity or cruelty, you must consider the presence and degree of the following factors: the deceased;

One: whether the defendant was indifferent to or took pleasure in the suffering of

Two: the consciousness and degree of suffering of the deceased;

Three: the extent of the injuries to the deceased;

Four: the number of blows delivered;

Five: the manner, degree and severity of the force used;

Six: the nature of the weapon, instrument or method used;

Seven: the disproportion between the means needed to cause death and those employed.

This seventh factor refers to whether the means used were excessive and out of proportion to what would be needed to kill a person.

Mass. Superior Court Jury Instructions §2.5.2 (Murder with Extreme Atrocity or Cruelty).

${ }^{28}$ If C2 suddenly discovers that a brutal method of killing brings him pleasure, but then continues to employ that method in the course of attacking the victim for the purpose of prolonging the pleasure, C2's motives are quite similar to C1's, and it is then clearly appropriate to consider his cruel motive in determining his punishment.
} 
Whatever the answer to this question, which is a question about the moral concept of cruelty, ${ }^{29}$ we should have serious qualms about imposing extra criminal punishment on C2 because of his attitude. Thus, contrast C2 with C3, who does not actually cause suffering to others, but who takes pleasure in another causing such suffering. (Suppose C3 enjoys watching a video clip of someone violently attacking another.) It seems accurate to describe $\mathrm{C} 3$ as possessing a cruel attitude, parasitic on an actual act of cruelty. But C3 is not properly subject to criminal punishment. ${ }^{30}$ So is there any reason that C2 is properly subject to greater punishment because of his own cruel attitude?

Here is one possible reason. When C2 realizes that he is deriving pleasure from his attack on the victim, he can do something: stop the attack or stop himself from feeling that pleasure. He is not simply a passive bystander to his own vicious reactions. In this respect, he is like an actor $\mathrm{R}$ who shouts racist slurs while attacking a victim; even if the racial identity of the victim played no role in R's decision to attack or in his method of attack, his failure to control his racist impulses reflects some degree of culpability. Still, it is doubtful that this argument adequately justifies the enormous punishment difference that the "pleasure in another's suffering” factor legally permits.

I raise these questions without fully resolving them. The discusssion does show that if we wish to limit the state's role to punishing for acts, not for vicious attitudes or character traits, we need to proceed very cautiously in permitting consideration of such attitudinal factors as remorse, hope, and cruelty.

\section{Other possible meanings of indifference}

Even if we restrict "culpable indifference" to attitudes that are appropriately expressed in, or that causally contribute to, action, we need to examine more closely which attitudes so qualify. I will suggest that a pluralistic account is most defensible.

However, we should resist two other possible interpretations of "culpable indifference" that have some currency but are inadequate. On one interpretation, culpable indifference is just a term of art for all culpable states of mind. ${ }^{31}$ Viewed this way, murder requires causing a death with, say, "extraordinary" or "extreme" culpable indifference, a term that encompasses causing a death purposely, knowingly, and also in other highly culpable ways or for other highly culpable reasons. This interpretation has little to commend it, for it leaves open the content of the third, residual category, and it simply stipulates rather than explains why these different states of mind ought to be treated the same for purposes of deserved punishment.

A second interpretation is more promising: perhaps causing harm with "culpable indifference" is properly punished about as harshly as purposely or knowingly causing harm because in all three cases, the actor displays the same moral

\footnotetext{
${ }^{29}$ That moral concept might include not only delight or pleasure in inflicting suffering on others, but also indifference to that suffering. See Hurka (2001), at 95-96.

${ }^{30}$ However, perhaps C3's contributing to the market for violent videos deserves punishment because it increases the risk that the violent acts depicted in the videos will occur.

${ }^{31}$ See Alexander \& Ferzan, occasionally endorsing this interpretation: "insufficient concern" is the term of art that they employ. For a critique, see Simons (2010), at 566-568.
} 
defect. As the Commentary to the Model Penal Code's extreme indifference murder provision suggests:

In a prosecution for murder ... the Code calls for the ... judgment whether the actor's conscious disregard of the risk, under the circumstances, manifests extreme indifference to the value of human life. The significance of purpose or knowledge as a standard of liability is that, cases of provocation or other mitigation aside, purposeful or knowing homicide demonstrates precisely such indifference to the value of human life. ${ }^{32}$

But the initial attraction of this argument fades upon analysis. What is the "precise" quality of moral indifference shared by all three kinds of murder? One who purposely kills another personally commits himself, via his means and ends, to bring about a serious harm and wrong. Normally this amounts to an especially culpable personal identification with evil. ${ }^{33}$ Knowingly (but not purposely) killing does not have these features. However, it usually does demonstrate a severe discounting of the rights of others relative to a socially acceptable valuation and, for this distinct reason, is especially culpable. ${ }^{34}$ And similarly, recklessly (but not knowingly) killing usually demonstrates a serious, but somewhat less severe, discounting of the rights of others.

In my view, there is a qualitative difference between purposeful harms, on the one hand, and knowing and reckless harms, on the other. The latter two categories do evince a similar kind of indifference in the sense of devaluation of the rights of victims. But, for reasons we have already explored, there is more to indifference than acting with cognitive awareness of likely or possible harm.

Consider a telling pair of examples offered by Professor Claire Finkelstein that illuminate the subtly different ways in which purpose and knowledge bear on an actor's culpability. Variations on the examples will also shed light on the way in which recklessness and recklessness-plus-culpable-indifference bear on culpability. The examples (which I have paraphrased) are unusual ones: the actor who knowingly causes death arguably displays greater culpability that does the actor who purposely causes death.

Two arsonists: E1 is the beneficiary of V1's life insurance policy. She sets fire to her own house where V1 is sleeping in order to collect. V1 dies in the fire.

E2 has a homeowner's policy on which she wants to collect, and sets fire to her own house, notwithstanding her knowledge that V2, who is sleeping in the house, will certainly die. Moreover, E2 knows that if she

\footnotetext{
${ }^{32}$ Model Penal Code comment to $\$ 210.2$.

33 See Nagel; Tadros.

${ }^{34}$ Notice, too, that one may purposely kill despite believing that one's chance of success is slight, e.g. if $\mathrm{D}$ shoots at the victim from a considerable distance because that is D's only chance of any success. Not all purposeful killings are knowing (whereas all knowing killings are reckless, in the sense that the knowing actor believes that he is imposing at least a substantial risk of death). This again underscores the qualitatively difference between the culpability expressed by purposeful killing and that expressed by knowing killing.
} 
waits an hour, V2 will have left the house. Nevertheless, E2 burns down the house now. V2 dies in the fire.

E2 seems more culpable than E1, but this contradicts the usual intuition that purposefully causing harm displays greater culpability than knowingly doing so. Here is Finkelstein's explanation:

The agent who does not have to kill to obtain her end, but does so anyway in a state of indifference, seems worse than the agent who must kill and does so in order to accomplish her end. The agent who intends to kill might place a higher intrinsic value on human life. Her actions are compatible with her having deep regret at having to kill to obtain her end. Agent 2, however, could not plausibly be said to place a high value on human life. She is indifferent to the prospect of killing, to the point where she would rather kill than suffer a minor inconvenience. ${ }^{35}$

But Finkelstein's analysis, while illuminating, does not undermine the general distinction between purposely and knowingly causing harm, nor does it demonstrate that indifference simply amounts to excessive devaluation of the rights of others. Ceteris paribus, acting with purpose is more culpable than acting with knowledge. E1 and E2 differ in a number of respects; if we control for those differences, the significance of the purpose/knowledge distinction becomes more salient. Thus, suppose two more variations.

E3 is a reckless (or "knowing risk") variation of E2, identical to E2 except that E3 is aware of a $5 \%$ chance (rather than near certainty) that the victim will die, and refuses to wait an hour to reduce that risk to zero.

E4 is a purposeful risk variation of E2. E4 is identical to E3 and E2 in her motive to burn down the house for the homeowner's insurance proceeds, and in refusing to wait an hour to reduce the risk of harm to the victim to zero. But E4 differs in this important respect: she endangers the victim purposely rather than knowingly, for the malicious pleasure she derives from frightening the victim. (She sets the fire in location A rather than location $\mathrm{B}$ because a fire set at $\mathrm{A}$ is much more likely to frighten the victim terribly.)

Because E4 has purposely and not merely knowingly created the risk of death, and has purposely and not merely recklessly frightened the victim, E4 is more culpable than E3. ${ }^{36}$

\footnotetext{
${ }^{35}$ Finkelstein (1996), at 340.

${ }^{36}$ In E4, the actor endangers $\mathrm{V}$ purposely, but does not act with the purpose of killing V.

We can also construct a contrasting scenario for E1. The fact that E1 regrets having to kill in order to obtain insurance money still makes her more culpable than an otherwise similarly situated actor E2* who regrets having to take an action that he knows will cause death, in order to obtain insurance money. Suppose the only time when E2* can set fire to his own house in order to obtain homeowner's insurance is when the victim is present.
} 
Nevertheless, Finkelstein's original examples E1 and E2 are instructive. E2 indeed seems to be highly culpable, and more culpable than most other actors who knowingly cause serious harm or death. Why? Because of the ease with which E2 could achieve her dominant end, obtaining insurance money, without causing such harm. More precisely, what is distinctive is the extraordinary weight E2 gives, not just to the primary end of obtaining financial gain, but also to the secondary and socially insignificant end of avoiding the inconvenience of waiting an hour. By contrast, in a knowing harm case where the only way the actor can achieve his primary end is to knowingly harm someone as a side effect, his conduct is not gratuitously harmful, so even if it is unjustified, it lacks that aggravating feature. Thus, suppose a new character, E2*, must burn the house down now in order to effectively destroy it; a delay will be fatal to that end. E2* is less culpable than E2. ${ }^{37}$

Let us now extend the analysis to recklessness plus culpable indifference. From the earlier discussion, we would expect: (a) acting with knowledge is ordinarily more culpable than acting with recklessness, but (b) a subcategory of recklessness cases is comparable to knowledge cases-namely, those that contain an aggravating factor of culpable indifference. And so we do find. As an illustration of (a), notice that E2 is more culpable than E3. For a plausible instance of (b), consider yet another arsonist, E5. E5 has the same beliefs and motives as reckless E3 except in one respect: she decides to turn off the video feed in the house that would tell her that the victim will very likely die in the fire, because she does not want to know. E5's “willful blindness," her decision to avoid knowledge, perhaps justifies punishing her more harshly than reckless E3 and as harshly as E2, who knows that the victim is very likely to perish.

Finkelstein frames the difference between the culpability of E2 and E1 as a difference in how much each actor intrinsically values human life, with purposeful killer E1, paradoxically, valuing the life of the victim more. This analysis is only partly right. E2's willingness to sacrifice a life for what E2 herself would concede to be a trivial interest in very briefly accelerating the timing of the arson demonstrates an extraordinary level of selfishness and moral depravity. But we should be wary of treating the difference between the actors as simply a difference in how much each actor subjectively values the life of another when the actor reasons practically toward her ends. Such an account is overly reductive. On such a view, a morally upstanding citizen gives (let us say) weight 10,000 to the disvalue of causing an innocent person's death; E1 improperly accorded that result a weight of only 100; and E2 is more culpable than E1 because he accorded that result an even lesser weight of 10. As tempting as this form of analysis is, it is incomplete and misleading. Whether an act is unjustified, and how unjustified and culpable it is, depends on a variety of factors, of which the actor's subjective valuation of the rights and interests of others is only one. Also highly relevant are the permissibility, nature, and significance of the actor's goals, the alternatives reasonably available to

\footnotetext{
${ }^{37}$ The analysis would be similar for new character E3*, who must burn down the house now in order to effectively destroy it; he is less culpable than E3, even if both actors create the same $5 \%$ risk of death.
} 
him, the facts reasonably accessible to the actor, the actor's assumed social role, the relationship and expectations of the parties, and so forth. ${ }^{38}$

But shouldn't the subjective valuation that the actor assigns to the rights and interests of others at least count as a critical factor? Especially in the present context, when we are evaluating whether a subcategory of reckless acts that threaten harm demonstrate culpability comparable to acts that purposely or knowingly cause harm? ${ }^{39}$ I do agree that analysis would be simpler if this factor were given controlling weight. The torturer gives much too little weight to his victim's continued life. Similarly for the person who shoots into an unoccupied car or home. Alas, culpability is simply not so simple. Recall that the torturer in the earlier example (D1) wanted to keep his victim alive, in order to prolong the sadistic pleasure he derived from his victim's pain. Considered in isolation, the torturer's valuation of the victim's life is not as low as in many other murder cases, yet his acts remain highly culpable. The malevolence and clear unjustifiability of the torturer's ends are critical to our judgment that he is highly culpable; it is hardly decisive that, in a narrow sense, he "devalues" the life of his victim less than most purposeful or knowing killers do, because he seeks to keep the victim alive for his nefarious purposes. Moreover, this "insufficient value" approach rests on a controversial mode of legal and moral analysis: that in judging degree of culpability, we must employ a sliding scale, judging the extent to which the actor deviates from either the result of the scale or the proper method of employing it. This mode of analysis will be congenial to many consequentialists, but not to many deontologists and retributivists, for familiar reasons.

In the end, the judgment that an actor is culpably indifferent to the harm he might do to another, or to his legal obligations, is a judgment that must depend on a plurality of features, features that cannot be reduced to "deficient valuation of human life," or to "culpable choice” or "culpable character." In such concrete contexts as how to interpret the "extreme indifference" murder category, a pluralistic approach is often employed. ${ }^{40}$ As a matter of principle, such a pluralistic approach is entirely justifiable.

\footnotetext{
${ }^{38}$ Thus, indifference or "caring less than one should" is not a single desire-state. Rather, it expresses what Holly Smith has called "a reprehensible configuration of desires and aversions." Smith, at 556. "Thus, a concern for one's own welfare is not bad in itself, nor bad even if very powerful, so long as it is counterbalanced by sufficiently strong aversions to harming others."

${ }^{39}$ Notice that the Model Penal Code's murder formulation uses the phrase "extreme indifference to the value of human life." It does not employ a formulation that would be more parallel to purposely or knowingly causing death (e.g. "extreme indifference to whether the actor would cause death"). This choice of language reveals how natural it is to emphasize deficient valuation when defining and explaining culpability criteria.

${ }^{40}$ Although some courts employ oversimplified criteria for "extreme indifference" murder, in practice many are sensitive to a range of considerations. Thus, they should, and often do, consider:

- Whether the actor intends to expose another to risk of a harm, either as a means or as an end (e.g. playing Russian Roulette, or deliberately firing a weapon at or driving a vehicle towards the victim in order to scare him);

- Whether the actor was motivated or moved by sadism, cruelty, pecuniary gain, or some other especially culpable, heinous or evil motive or intention;

- Whether the actor's anger, racism, or other culpable desires or emotions causally contribute to his conduct;
} 


\section{Culpable indifference and the Doctrine of Double Effect}

The lessons from Finkelstein's examples and the further variations noted above shed some light on a familiar philosophical problem: the standard Doctrine of Double Effect (DDE) scenarios of Terror Bomber (TB) and Strategic Bomber (SB). Under DDE, it is much more difficult to justify intentionally causing a harm as a means or end, than to justify causing such a harm as a foreseen side effect. ${ }^{41}$ Suppose the military on the just side of a conflict can prevent the opposing side from carrying out an imminent plan to destroy a village, killing 1,000 people, only by immediately bombing an enemy camp. Unfortunately, bombing the camp will kill 20 innocent civilians as a side effect. ${ }^{42}$ SB might well be justified in bombing the camp. Contrast a TB scenario: the military can prevent the imminent destruction of the village and 1,000 deaths only by sending in TB to deliberately target and kill 20 innocent civilians. The point of this bombing mission is to terrorize the opposing side; the military strategists know that the mission will cause the enemy to abandon its plan to destroy the village and its inhabitants. ${ }^{43}$

DDE tells us that SB might be acting permissibly even though TB is acting impermissibly. But DDE also tells us that even if a strategic bomber acts impermissibly-for example, because the expected harm to civilians is just large enough to outweigh the expected military advantage- - he is less culpable than TB. ${ }^{44}$ Consider a different strategic bomber, SB2, who knows that bombing the enemy camp is likely to kill 200 (rather than 20) innocent civilians, and suppose that this expected harm to civilians is just large enough to outweigh the expected military advantage and render the action impermissible. DDE suggests that SB2 is less culpable than TB2, who, like SB2, knowingly kills 200 innocent civilians, but,

- Whether the risk of harm arose from the actor's choice to participate in an immoral or illegal activity;

- Whether the actor successively created multiple risks over a short period of time;

- As a mitigating factor, whether the actor attempted to avoid or reduce the risk of harm.

See Simons, Culpable Indifference, at 307-313.

${ }^{41}$ The DDE literature is voluminous. A recent survey is FitzPatrick. For a recent defense, see Wedgwood.

${ }^{42}$ Here I will employ a variation on Victor Tadros's version, which, helpfully, is more concrete than usual versions that describe the benefit of strategic bombing only as some vague "significant military advantage.” Tadros, at 204. I have changed the target from a munitions plant to an enemy camp, and have changed the number of civilian casualties from Tadros's 100 to 20 to make it more plausible that the knowing killing of the civilians is permissible.

${ }^{43}$ The standard TB scenarios such as this are highly unrealistic in modern warfare, given the likelihood that such atrocities will be publicized by modern media. Clear evidence that innocent civilians have been deliberately targeted is probably more likely to stiffen the other side's resolve than to bully them into a change of plans. But I will stick with the familiar SB/TB scenarios because of their prominence in the literature.

${ }^{44}$ Some view DDE more narrowly, as a principle that distinguishes only between impermissible and permissible acts (and that places purposeful harms in the impermissible category and knowing harms in the permissible category, so long as the foreseen harm is "proportional"). But on a broader view, DDE also is relevant to the question of the degree to which the act is unjustifiable or culpable: acts that purposely cause harm are more unjustifiable or more culpable than acts that knowingly cause harm even when the latter acts are impermissible. 
unlike SB2, does so deliberately in order to terrorize the enemy into abandoning its plan.

Now compare another variation, SB3, analogous to arsonist E2. Let us fill in certain details. Suppose SB3, like SB2, attacks the enemy camp during the daytime, and he expects 200 children at the adjacent school to die as a side effect. In SB2's case, the bombing must be done immediately, or else the village and its inhabitants will be destroyed by the enemy. In SB3's case, the bombing must be done within two hours, because it is known that the enemy will attack then but no earlier. SB3 knows he could wait an hour until the children have left the school, without diminishing the probability that his bombing missions will succeed. But he decides to bomb the school now, in order to get the bombing run over with sooner (and thus to see more of the World Cup final). SB3 is clearly more culpable than SB2, just as E2 is clearly more culpable than E2*. ${ }^{45}$ And we can imagine more variations along the same lines. ${ }^{46}$

One general lesson from this analysis is as follows. DDE, as conventionally formulated, only distinguishes between purpose and knowledge (whether the question at issue is an act's permissibility or instead concerns its degree of unjustifiability or of culpability). But if we add the dimension of culpable indifference, we can identify cases on the "knowledge" (or recklessness) side of the line that are especially culpable. SB3 is such a case. We can thus partially blunt the common and well-taken objection that DDE too readily justifies acts that bring about known but not intended harmful consequences.

\section{Some implications for moral blame}

These observations about the proper use of legal criteria of culpable indifference have some implications for moral blaming practices. Moral philosophers have devoted much more attention to whether an act is blameworthy, or whether an actor is morally responsible for an act, than to how blameworthy the act or actor is. The legal culpability criteria analyzed above can, I believe, help illuminate this last question.

Insofar as we justifiably blame one another for wrongful conduct, many of the considerations mentioned above are quite relevant. When criminal wrongs are also moral wrongs, the analysis above largely applies: you ought to blame your child, spouse, friend, or neighbor more for purposely causing serious harm than for knowingly causing such harm, and so forth. ${ }^{47}$ Of course, the scope of criminal law is

\footnotetext{
${ }^{45}$ Interestingly enough, although (knowing) E2 seems more culpable than (purposeful) E1, (knowing) SB3 does not seem more culpable than (purposeful) TB. One reason is that to kill for the purpose of terrorizing a civilian population is to kill for an especially evil motive.

${ }^{46}$ Thus, suppose SB4 knows he could either bomb location $\mathrm{X}$ or location $\mathrm{Y}$ in order to prevent the destruction of the village, but bombing $X$ will get him back to base sooner, yet bombing $X$ will kill a few more civilians than will bombing Y. Like SB3, SB4 is clearly more culpable than SB2.

${ }^{47}$ However, blaming practices may differ from punishment practices in the following important respect. Punishment practices often require hierarchical rankings of the degree of wrong, because punishment typically is translated into a scalar currency such as amount of a fine or amount of prison time. By contrast, blaming practices can take the form of more nuanced responses to different types
} 
limited; it does not address all moral wrongs. If a right or interest is too slight to deserve criminal law protection, or if countervailing reasons of policy or principle militate against criminalization, we can still ask what degree of moral blame an actor deserves for violating the right or setting back the interest. Thus, we could apply much of the analysis above to a variety of contexts that are subject to only minimal criminal law regulation, such as lying, breaking a promise, acting discourteously, or offending another's sensibilities.

Consider this example. Suppose a co-worker causes you emotional harm (a type of harm that is only rarely addressed in the criminal law unless accompanied by risks of physical harm). In judging how blameworthy he is for bringing about this harm, the hierarchy of purpose, knowledge, recklessness, and negligence is somewhat informative. He is more culpable if he openly questions your ability in the presence of other workers for the purpose of causing you emotional distress, than if he knowingly causes such distress as a byproduct of a more legitimate activity (such as writing a critical review of your work). Even if he was not justified in the latter case (e.g. because he really has very little knowledge of the quality of your work), he is less culpable for causing you emotional harm knowingly rather than purposely. And if he was merely reckless as to causing you emotional harm, this will ordinarily be less culpable-unless he also displayed some form of culpable indifference that elevates his recklessness to a culpability level comparable to knowledge. For example, it is merely reckless to write a negative job evaluation when one is insufficient familiar with the person's work and recognizes that the person might find the review upsetting. However, it is more culpable to do so for an improper motive-for example, because another co-worker bribed you to write your (honest) evaluation when you were otherwise disinclined to do so.

But the scope of deserved moral blame is much wider than the scope of deserved blame for purposes of criminal punishment, quite apart from the types of acts that are properly understood as wrongful in each domain, and it is wider in two very different ways. First, the point of examining desert for purposes of punishment is to identify the legitimate preconditions of rendering the wrongdoer liable to state coercion; and the forms of coercion are potentially quite severe. But in private blaming contexts, a separate, important reason for examining the desert basis exists-namely, to consider how the wrongdoer should respond to the wrong he has already committed. Perhaps he should apologize to the victim. Or compensate him. Or accept responsibility by resolving to improve his character in the future. The kind of response that morality requires or supports here is quite sensitive to the desert basis, and the hierarchy of culpability will often be relevant. ${ }^{48}$

of wrongs; there is often no need to translate them into a single currency. One might respond quite differently to a friend's intentional lie, for example, than to the friend's negligent misstatement; the first moral wrong might deserve reproach and expressed concern about whether the trust within the relationship has been irreparably violated, but the second might deserve immediate forgiveness. I thank Antony Duff for raising this point.

${ }^{48}$ But a response can of course be morally required even if the original action triggering the duty to respond is not a moral wrong. If I faultlessly run over your dog, I should apologize. And if, without any fault, I bump you into the path of a speeding bicycle, I should try to save you from further injury, even at some risk to my own safety. 
Second - and here the distinction from criminal law is even more stark-we are often justified in blaming someone simply for his vicious attitudes, whether or not those attitudes played a causal role in bringing about a wrongful act or harm. If my child takes delight in another's suffering, or lacks remorse for a wrongful (or even a nonwrongful) act, or hopes that another will suffer harm, I would rightly reproach him. If someone commits a serious crime but immediately thereafter returns to his ordinary life, calmly munching a sandwich, ${ }^{49}$ or joining friends for dinner, or interacting with others as if nothing had happened, the popular reaction will be swift and severe: the actor is especially blameworthy because of his callousness and shamelessness. ${ }^{50}$ That reaction is perfectly justifiable. Of course, such blameworthiness is categorically distinct from being blameworthy for a culpable state of mind that is appropriately connected to engaging in a wrongful action. Only the latter is directly relevant to deserved criminal punishment.

Indeed, the moral culpability that an actor displays in a harmful or wrongful act sometimes pales into insignificance as compared to the moral culpability he displays by his malicious or callous response to the first wrong. Suppose my son, rushing off to high school in his car, accidentally runs over the neighbor's cat. He finds the mangled body strangely amusing, and posts it on Facebook for the world to see. I would (rightly) reproach him much more severely for his insensitive reaction to the first wrong than for the wrong itself.

The first-order vice of callous indifference, and the second-order vice of shamelessness, are legitimate bases for blame, resentment, and similar reactive attitudes. These vices are characteristically displayed in wrongful acts, and we usually only become aware that someone possesses such traits through his actions and statements. But in principle it seems that an actor could be indifferent without that attitude playing any role in his primary conduct. Perhaps an agent who is in a permanent state of complete emotional detachment from his conduct and choices and from their effect on others could nevertheless act in perfect accord with his moral duties. Virtue ethics and deontological ethics may have radically different domains.

\section{Conclusion}

When we punish and blame for wrongful acts, we should look beyond the cognitive dimensions of the actor's culpability, and should consider affective and volitional dimensions as well, including the actor's intentions, motives, and attitudes. But we must proceed carefully when permitting criminal liability to turn on such attitudes as culpable indifference, lest we punish vicious or unvirtuous feelings that are not sufficiently connected to wrongful acts, and lest we punish disproportionately for attitudes that reflect only a very modest degree of culpability.

\footnotetext{
${ }^{49}$ Consider Robert Alton Harris, who gratuitously killled two teenagers in the course of stealing their car to commit a bank robbery; after the killing, he ate their unfinished lunch. Pillsbury, at 118.

${ }^{50}$ See Hurka (2001), at 95, noting that "shamelessness" is a second-order vice, involving indifference to his own evil act, a vice Hurka characterizes as less serious than moral depravity, which is a delight in the moral evil that one has committed.
} 


\section{References}

Alexander, L \& Ferzan, K., with Morse, S., Crime and Culpability: A Theory of Criminal Law. Cambridge: Cambridge University Press 2009.

Baron, M. 'The Standard of the Reasonable Person in the Criminal Law' , in The Structures of the Criminal Law, ed. R.A. Duff, Lindsay Farmer, S.E. Marshall, Massimo Renzo, \& Victor Tadros. Oxford: Oxford University Press 2012.

Blomsma, J., Mens Rea and defences in European criminal law, Intersentia: 2012.

Duff, R.A., 'Criminal Responsibility and the Emotions: If Fear and Anger Can Exculpate, Why Not Compassion?' , Inquiry _ (2015) (forthcoming)

Duff, R.A., 'Virtue, Vice, and Criminal Liability: Do We Want an Aristotelian Criminal Law?’ , Buffalo Criminal Law Review 6 (2002).

Commonwealth v. Malone, 47 A.2d 445, Pa., 1946.

Ferzan, K., 'Don't Abandon the Model Penal Code Yet!: Thinking Through Simons's Rethinking', Buffalo Criminal Law Review 6 (2002).

Finkelstein, C., 'The Inefficiency of Mens Rea', California Law Review 88 (2002).

Finkelstein, C., 'The Irrelevance of the Intended to Prima Facie Culpability: Comment on Moore' , Boston University Law Review 76 (1996).

FitzPatrick, W., 'The Doctrine of Double Effect: Intention and Permissibility' , Philosophy Compass 7/3, 2012.

Fletcher, G., The Grammar of Criminal Law: American, Comparative, and International,Vol. I. Oxford: Oxford University Press 2007.

Hurka, T., Virtue, Vice and Value. Oxford: Oxford University Press, 2001.

Hurka, T., 'Virtuous Act, Virtuous Disposition', Analysis 66 (2006).

Mass. Gen. L. Ann. $265 \S 1$.

Mass. Superior Court Jury Instructions §2.5.2 (Murder with Extreme Atrocity or Cruelty), Massachusetts Continuing Legal Education, Inc., 2013.

Model Penal Code, Part II, §210.2, cmt. 4, Official Draft and Revised Comments 1980.

Model Penal Code (Proposed Official Draft 1962).

Nagel, T., The View From Nowhere. Oxford: Oxford University Press 1986.

People v. Roe, 542 N.E.2d 610, N.Y.,1989.

Pillsbury, S., Judging Evil: Rethinking the Law of Murder and Manslaughter. New York: New York University Press, 1998.

Shen, F., et al, 'Sorting Guilty Minds', New York University Law Review 86 (2011).

Simons, K., 'Book Review: Retributivism Refined-Or Run Amok?' , University of Chicago Law Review 77 (2010).

Simons, K., 'Culpability and Retributive Theory: the Problem of Criminal Negligence' , Journal of Contemporary Legal Issues 5 (1994).

Simons, K., 'Does Punishment for "Culpable Indifference” Simply Punish for "Bad Character”?’ , Buffalo Criminal Law Review 6 (2002).

Simons, K., 'Dimensions of Negligence in Criminal and Tort Law' , Theoretical Inquiries in Law 3 (July 2002).

Simons, K., 'Rethinking Mental States’ , Boston University Law Review 72 (1992).

Simons, K., 'Statistical Knowledge Deconstructed' , Boston University Law Review 92 (2012). 
Smith, H., 'Culpable Ignorance’ , Philosophical Review 92 (1983).

Tadros, V., The Ends of Harm: The Moral Foundations of Criminal Law. Oxford: Oxford University Press, 2011.

Wedgwood, R., 'Defending Double Effect' , Ratio (new series) XXIV (2011). 